\title{
Students First: The Need for Adoption of Education and Incentive-Based Sport Agent Policies by NCAA Division I FBS Member Institutions
}

\begin{abstract}
Alicia Jessop*
The Federal Bureau of Investigation ("FBI") and U.S. Attorney's Office's investigation into National Collegiate Athletic Association ("NCAA") Division I men's basketball revealed allegations of NCAA Division I men's basketball coaches accepting money from sport agents to persuade NCAA Division I men's basketball players to become clients of said sport agents. This investigation highlights the pervasiveness of violations of preexisting laws governing sport agents, namely, the Uniform Athlete Agents Act (the "UAAA") and Sport Agent Responsibility and Trust Act ("SPARTA"). Despite the believed routine violation of the UAAA and SPARTA in the recruitment of NCAA student-athletes as clients by sport agents, the laws are rarely used to prosecute sport agents. Thus, the investigation into NCAA Division I men's basketball highlights the need for new mechanisms to safeguard the rights and interests of NCAA student-athletes related to sport agents. This paper analyzes the efficacy of existing legal and NCAA mechanisms regulating sport agents and presents a thematic analysis of NCAA Division I Football Bowl Subdivision ("FBS") member institutions' sport agent policies to highlight the need for and present a model NCAA Division I FBS member institution sport agent policy and education model.
\end{abstract}

Keywords: NCAA, Division I, collegiate men's basketball, sport agent, studentathlete

\section{Introduction}

Shockwaves rolled through the National Collegiate Athletic Association ("NCAA") Division I men's basketball landscape in the fall of 2017 when 10 individuals connected to the sport were arrested amidst a three-year Federal Bureau of Investigation ("FBI") investigation into "... the criminal influence of money on coaches and student-athletes who participate in intercollegiate

\footnotetext{
* Alicia Jessop, JD, is an associate professor in the Communication Division of Seaver College at Pepperdine University; email: Alicia.Jessop@pepperdine.edu.
} 
basketball governed by the NCAA."1 The FBI's investigation uncovered allegations of payments by sport agents and financial advisors to NCAA Division I men's basketball coaches in an attempt to bribe those coaches to direct players to the sport agents' and financial advisors' services. ${ }^{2}$ Ten individuals, including two representing professional athletes as agents or financial advisors and four NCAA Division I coaches, were arrested as a result of the FBI's investigation. The individuals arrested faced charges of bribery conspiracy, solicitation of bribes, honest services fraud conspiracy, honest services fraud, wire fraud conspiracy, Travel Act conspiracy, and money laundering conspiracy. ${ }^{3}$ The arrests of and charges against NCAA Division I men's basketball coaches in conjunction with the FBI's investigation highlight inadequacies of the NCAA Division I Manual's bylaws and current state and federal legislation to protect the rights and interests of NCAA Division I student-athletes from unscrupulous sport agents.

Central to the NCAA's model of governance is a standard of amateurism, ${ }^{4}$ whereby NCAA student-athletes are not to be compensated for their athleticism beyond a total cost of attendance scholarship. ${ }^{5}$ Related to its standard of amateurism, the NCAA has placed limitations on when and how NCAA student-athletes can engage and interact with sport agents, ${ }^{6}$ specifying that an NCAA student-athlete loses his or her amateur status by entering "... into an agreement with an agent."7 The NCAA Division I Manual details the types of interactions and exchanges with sport agents that cause an NCAA student-athlete to lose his

\footnotetext{
${ }^{1}$ See U.S. Attorney Announces The Arrest Of 10 Individuals, Including Four Division I Coaches, For College Basketball Fraud And Corruption Schemes, UNITED STATES DEPARTMENT OF JUSTICE, Sept. 26, 2017, https://www.justice.gov/usao-sdny/pr/us-attorney-announces-arrest-10-individuals-including-four-division-i-coaches-college (detailing the FBI's investigation into alleged improprieties in NCAA Division I men's basketball and highlighting charges against ten individuals).
}

2 See John Gasaway, What you need to know about the FBI's NCAA basketball investigation, ESPN, Sept. 26, 2017, http://www.espn.com/mens-college-basketball/story//id/20826573/ what-need-know-fbi-ncaa-basketball-investigation (highlighting key facts surrounding the FBI's investigation into allegations of corruption and bribery in Division I men's basketball).

${ }^{3}$ See U.S. Attorney Announces The Arrest Of 10 Individuals, supra note 1.

${ }^{4}$ See Nat'l Collegiate Athletic Ass'n, 2017-2018 nCAA Division I Manual, Bylaw 12.01.1 (2017), available at http://www.ncaapublications.com/productdownloads/D118.pdf (specifying, "Only an amateur student-athlete is eligible for intercollegiate athletics participation in a particular sport.").

${ }^{5}$ Id. at Bylaw 15.1 ("A student-athlete shall not be eligible to participate in intercollegiate athletics if he or she receives financial aid that exceeds the value of the cost of attendance. . . A student-athlete may receive institutional financial aid based on athletics ability. . . and educational expenses. . . up to the value of a full grant-in-aid, plus any other financial aid up to the cost of attendance. ..").

${ }^{6}$ Id. at Bylaw 12.3.1 ("An individual shall be ineligible for participation in an intercollegiate sport if he or she ever has agreed (orally or in writing) to be represented by an agent for the purpose of marketing his or her athletics ability or reputation in that sport. Further, an agency contract not specifically limited in writing to a sport or particular sport shall be deemed applicable to all sports, and the individual shall be ineligible to participate in any sport.").

${ }^{7}$ Id. at Bylaw 12.1.2 (g). 
or her amateur status and, subsequently, NCAA eligibility. ${ }^{8}$ It also allows for the creation of Professional Sports Counseling Panels ("PSCPs") to educate and advise NCAA student-athletes on issues involving and related to sport agents. However, the NCAA Division I Manual does not provide details or guidance on the type and content of education and advice to be given by PSCPs. ${ }^{9}$ In this regard, NCAA Division I athletic departments have wide latitude in the type and content of education they provide NCAA student-athletes and coaches on sport agents. Furthermore, while every NCAA Division I student-athlete must uphold the NCAA's standard of amateurism, including how it relates to sport agents, Division I member institutions can adopt sport agent-related policies extending beyond the reach of those provided in the NCAA Division I Manual. ${ }^{10}$

Along with the NCAA's bylaws surrounding NCAA student-athlete and sport agent dealings, individual states ${ }^{11}$ and the federal government ${ }^{12}$ have legislated around the relationship. Notably, none of the 10 individuals charged amidst the FBI's three-year investigation into alleged corruption and bribery in Division I NCAA men's basketball were charged with violating state or federal statutes related to sport agents. ${ }^{13}$

Despite NCAA, state, and federal legislation regulating the relationship between NCAA student-athletes and sport agents, violations of the standards set by these regulatory frameworks occur. ${ }^{14}$ These violations lead some to question whether the existing regulatory framework is strong enough to protect NCAA student-athletes' interests against unscrupulous sport agents. ${ }^{15}$

\footnotetext{
${ }^{8}$ Id. at Bylaw 12.3.

${ }^{9}$ Id. at Bylaw 12.3.4.

${ }^{10}$ See Id. (demonstrating the reach of the NCAA's policies on sport agent relationships and interactions with NCAA student-athletes and not defining the NCAA as the sole author of policies on sport agents in NCAA intercollegiate athletics).

${ }^{11}$ See Uniform Law Commission, Legislative Fact Sheet-Athlete Agents Act, http://www. uniformlaws.org/LegislativeFactSheet.aspx?title $=$ Athlete $\% 20$ Agents\%20Act (last visited January 16,2018 ) ("This act governs relations among student athletes, athlete agents, and educational institutions. It protects the interests of student athletes and academic institutions by regulating the activities of athlete agents.").

12 See Sport Agent Responsibility and Trust Act, 15 U.S.C. $\S$ 7801-7804 (2018).

${ }^{13}$ See UNITED STATES DEPARTMENT OF JUSTICE, supra note 1 (demonstrating that the charges against the ten individuals charged in the FBI's investigation into alleged corruption and bribery in NCAA Division I men's basketball do not include charges for violating the Sports Agent Responsibility and Trust Act or appropriate versions of the Uniform Athletes Agents Act).

${ }^{14}$ E.g., Ex-NFL agent Terry Watson pleads guilty to giving cash to 3 former UNC players, ESPN, April 17, 2017, http://www.espn.com/college-football/story/_id/19180813/ex-nfl-agent-pleadsguilty-multi-year-north-carolina-tar-heels-sports-agent-probe.

${ }^{15}$ See Violation of sports agent laws tough to prosecute, USA TODAY (Nov. 1, 2017), https:// www.usatoday.com/story/sports/ncaab/2017/11/01/violation-of-sports-agent-laws-tough-for-statesto-prosecute/107223304/ (last visited May 8, 2018) (discussing the unscrupulous methods utilized by some sport agents to sign amateur athletes and the hurdles the NCAA and government must undergo to protect NCAA student-athletes and prosecute agents for illegal conduct).
} 
Given these concerns, it is important to evaluate the current regulatory structure related to relationships between NCAA student-athletes and sport agents along with individual NCAA Division I Football Bowl Subdivision ("FBS") member institutions' sport agent policies to identify additional safeguards that could be instituted to better protect NCAA student-athletes from unscrupulous agents. This article presents a thematic analysis of NCAA Division I FBS athletic departments' sport agent policies. The purpose of the thematic analysis is to identify trends among NCAA member institutions' sport agent policies to present standards of best practice for schools to adopt in crafting sport agent policies better serving the needs and interests of NCAA student-athletes and creating incentives for sport agents to follow said policies.

Section I of the article outlines relevant state and federal laws governing the relationship between sport agents and NCAA student-athletes. Section II highlights the regulation of the relationship between sport agents and NCAA Division I student-athletes by the NCAA Division I Manual. Section III provides a review of the relevant literature in the area of sport agent regulations related to NCAA student-athletes. Section IV discusses the FBI's investigation into Division I men's basketball to explain how this investigation demonstrates the need for a model NCAA Division I member institution-based policy on sport agents. Section V highlights the method of thematic analysis utilized in this article. Section VI presents the results of the thematic analysis of NCAA Division I FBS member institutions' sport agent policies. Finally, Section VII provides a discussion on the results of the thematic analysis, arguing for the adoption of a model education and incentive-based sport agent policy by NCAA Division I FBS member institutions to best protect NCAA student-athletes and motivate compliance by sport agents.

\section{State and Federal Regulation of Sport Agents}

The profession of sport agents in the United States is regulated at the state and federal government levels.

\section{A. State Law Regulations of Sport Agents}

States largely model their regulation of sport agents after the Uniform Athlete Agents Act ("UAAA"), a model law approved and recommended for enactment in all states by the National Conference of Commissioners on Uniform State Laws in $2000 .{ }^{16}$ Highlighting the motivation behind drafting the model law, the National Conference of Commissioners wrote, “... the practices of a minority of agents or would-be agents in obtaining the right to represent athletes who may produce substantial fees for their agents have caused serious problems for student-athletes and educational institutions." ${ }^{17}$ Recognizing this, in conjunction with the varied nature of state regulation on sport agents existing in 2000, the

\footnotetext{
${ }^{16}$ Uniform Athlete Agents Act (2000).

${ }^{17} I d$.
} 
commission sought to create uniformity in how sport agents are regulated from state to state. ${ }^{18}$

As adopted by the National Conference of Commissioners on Uniform State Laws, the UAAA contains certain requirements agents must adhere to when recruiting student-athletes who are located within adopting states' borders. First, sport agents must register in states that have adopted a version of the UAAA prior to recruiting student-athletes within the state. ${ }^{19}$ To register, agents submit a registration form containing answers to questions related to the agent's education, training, career experience, business operations, and criminal history. ${ }^{20}$ Sport agents pay application, registration, and renewal fees, which are set by each adopting state. ${ }^{21}$ Sport agents' contracts with student-athletes are required to include specific information, including the agent's fee structure; the names of any third parties who will be paid because of the student-athlete signing with the agent; expenses the student-athlete will reimburse; a description of the agent's services; the duration of the agreement; and the contract date. ${ }^{22}$ The act also mandates agents to maintain records related to athletes they have represented for a period of five years. ${ }^{23}$ Along with the noted requirements, the UAAA prohibits certain conduct by agents. Notably, sport agents cannot provide false information or promises; provide student-athletes anything of value before entering into the contract; provide anything of value to anyone other than the student-athlete or another sport agent; or fail to notify a student-athlete that signing a contract with a sport agent could nullify his or her intercollegiate athletic eligibility. ${ }^{24}$

Agents in violation of the UAAA can be found guilty of a misdemeanor or felony, depending upon the structure of the respective state's criminal penalty section under the act. ${ }^{25}$ States also have latitude in determining how convictions for violations of the UAAA are punished. ${ }^{26}$ Notably, the act also creates civil remedies for educational institutions and NCAA student-athletes against sport agents whose conduct caused them to suffer damages. ${ }^{27}$ As of 2018, 40 states, along with the District of Columbia and the U.S. Virgin Islands, have adopted a version of the UAAA. ${ }^{28}$

\footnotetext{
${ }_{18} I d$.

19 Id. at $\S 4$.

${ }^{20} I d$. at $\S 5$.

${ }^{21} I d$. at $\S 9$.

${ }^{22} I d$. at $\S 10$.

${ }^{23} I d$. at $\S 13$.

${ }^{24} I d$. at $\S 14$.

${ }^{25} I d$. at $\S 15$.

${ }^{26} I d$.

${ }^{27} I d$. at $\S 16$.

${ }_{28}$ Uniform Law Commission, Legislative Fact Sheet-Athlete Agents Act, http://www.uniformlaws.org/LegislativeFactSheet.aspx?title=Athlete $\% 20$ Agents $\% 20$ Act (listing the states and U.S. districts and territories that have adopted the UAAA).
} 


\title{
B. Federal Regulation of Sport Agents
}

At the federal level, sport agents are regulated by the Sport Agent Responsibility and Trust Act ("SPARTA"). Enacted in 2004, SPARTA governs the relationship between "athlete agents" and "student athletes." As defined by the act, an "athlete agent" is one "... who enters into an agency contract with a student athlete, or directly or indirectly recruits or solicits a student athlete to enter into an agency contract ..." A "student athlete" is one "... who engages in, is eligible to engage in, or may be eligible in the future to engage in, any intercollegiate sport." 29

SPARTA makes it illegal for agents to recruit student-athletes to sign agency contracts by providing false or misleading information or anything of value to the student-athlete or his or her associates. Additionally, SPARTA requires agents to make disclosures during the recruitment process to student-athletes, or if they are under the age of 18 years old, to their legal guardians. The disclosure must be signed and contain the following notice near the signature block:

\begin{abstract}
Warning to Student Athlete: If you agree orally or in writing to be represented by an agent now or in the future you may lose your eligibility to compete as a student athlete in your sport. Within 72 hours after entering into this contract or before the next athletic event in which you are eligible to participate, whichever occurs first, both you and the agent by whom you are agreeing to be represented must notify the athletic director of the educational institution at which you are enrolled, or other individual responsible for athletic programs at such educational institution, that you have entered into an agency contract. ${ }^{30}$
\end{abstract}

If the requirement made under the disclosure is not met, SPARTA allows the educational institution to file a civil action against the athlete agent for actual losses and expenses incurred as a result of being unaware of the execution of the agency contract. Along with these damages, the prevailing party can be awarded costs and reasonable attorney's fees. ${ }^{31}$ Seeking remedies under SPARTA does not prohibit any plaintiff from utilizing other remedies available. ${ }^{32}$

The Federal Trade Commission enforces SPARTA and violations are treated as unfair or deceptive acts or practices under the Federal Trade Commission Act. ${ }^{33}$ Additionally, states' attorney general have the power to bring civil actions to enjoin practices violating SPARTA, enforce compliance with SPARTA, and obtain damages, restitution, and other compensation caused by violations of the law. ${ }^{34}$

\footnotetext{
29 Definitions, 15 U.S.C. $§ 7801$ (2018).

30 REgulation of UNFAIR AND DECEPTIVE ACTS AND PRACTICES IN CONNECTION WITH THE CONTACT BETWEEN AN ATHLETE AGENT AND A STUDENT ATHLETE, 15 U.S.C. $§ 7802$ (2018).

31 Protection of educational institution, 15 U.S.C. $\$ 7805$ (2018).

32 Limitation, 15 U.S.C. $\$ 7806$ (2018).

33 Enforcement, 15 U.S.C. $\$ 7803$ (2018).

34 Actions by States, 15 U.S.C. $\$ 7804$ (2018).
} 


\section{NCAA Division I Manual Regulation of the Relationship Between NCAA Division I Athletes and Sport Agents}

Along with state and federal regulations, the relationship between NCAA Division I student-athletes and sport agents is regulated by the NCAA Division I Manual. Central to the NCAA model of intercollegiate athletics governance is a standard of amateurism. Broadly stated, the amateurism standard requires that every NCAA student-athlete be an amateur to be eligible to compete in NCAA athletics. ${ }^{35}$ In terms of compensation, NCAA student-athletes maintain their amateurism by not being compensated for their athleticism beyond a total cost of attendance scholarship. ${ }^{36}$ The NCAA Division I Manual enumerates other ways NCAA Division I student-athletes can lose their amateur status, and subsequently, become ineligible to compete in NCAA athletics. ${ }^{37}$

The NCAA Division I amateurism standard applies to interactions between NCAA Division I student-athletes and sport agents. As defined in the NCAA Division I Manual,

An agent is any individual who, directly or indirectly: (a) Represents or attempts to represent an individual for the purpose of marketing his or her athletics ability or reputation for financial gain; or (b) Seeks to obtain any type of financial gain or benefit from securing a prospective student-athlete's enrollment at an educational institution or from a student-athlete's potential earnings as a professional athlete. ${ }^{38}$

Since 2012, the NCAA has defined agents to include certified contract advisors, financial advisors, marketing representatives, brand managers, and their employees. The NCAA notes this is not an exhaustive list of the types of professionals who could be considered an agent under the purview of the NCAA Division I Manual. ${ }^{39}$

As it relates to sport agents, there are a number of ways NCAA Division I student-athletes can lose their amateur status and become ineligible for NCAA competition. The first way amateur status can be lost related to sport agents is for an NCAA Division I student-athlete to enter "... into an agreement with an agent. ${ }^{" 40}$ The agreement can be made orally or in writing and also applies to agreements made for an agent to represent an NCAA student-athlete in the future. ${ }^{41}$ Additionally, an NCAA Division I student-athlete taking compensation or accepting a promise of payment related to athletic skill from a sport agent

\footnotetext{
35 Nat'l Collegiate Athletic Ass'N, supra note 4 at Bylaw 12.01.1.

36 Id. at Bylaw 15.1.

37 See Id. at Bylaws 12.1.2 - 12.1.2.3.

38 Id. at Bylaw 12.02.1.

${ }^{39}$ Id. at Bylaw 12.02.1.1.

${ }^{40} \mathrm{Id}$. at Bylaw 12.1.2 (g).

${ }^{41}$ Id. at Bylaw 12.3.1 - 12.3.1.2.
} 
loses his or her amateur status. ${ }^{42}$ The NCAA Division I manual defines "compensation" relatively broadly, as it includes transportation for both the NCAA Division I student-athlete and his or her family. ${ }^{43}$ Similarly, an agent reimbursing or paying the expenses of an NCAA Division I student-athlete would cause the student-athlete to lose his or her amateur status. ${ }^{44}$

While the NCAA Division I Manual strictly limits how NCAA student-athletes can interact with sport agents and remain eligible, it allows for the creation of a PSCP by member institutions. Among other things, the panels can advise NCAA student-athletes about future professional careers in athletics, review proposed professional sport contracts, communicate with professional teams regarding the NCAA student-athlete, and assist the NCAA student-athlete in selecting an agent. Panel members are appointed by the member institution's respective president or chancellor and the panel must be composed of at least three individuals, the majority of which are full-time, non-athletics department employees. Sport agents and individuals employed by sport agents or agencies are barred from serving on the panels. ${ }^{45}$

\section{Literature Review}

Much has been written by the academy regarding the relationship between sport agents and NCAA student-athletes. The vast majority of articles published in this area center on the types of regulations necessary to govern the relationship and analyzing the efficacy of existing regulations. Very little research exists on how to best educate NCAA student-athletes on the role of a sport agent and how to select a sport agent. Similarly, very little exists on NCAA member institutions' policies regarding sport agents and how NCAA member institutions can develop policies to best protect NCAA student-athletes' interests, while creating incentives for sport agents to adhere to said policies.

Beginning in the late-1980s, a significant amount of research was published calling for the need to regulate sport agents at the federal and state levels. Dunn (1988) argued Congress should enact preemptive federal legislation implemented by players' associations in the wake of rising professional athlete salaries to protect them from "incompetent and unethical" sport agents. ${ }^{46}$ In contrast, Rypma (1990) asserted state regulation of sport agents would more effectively protect the interests of athletes, since "... the regulation of professional occupations, such as medical doctors and lawyers, is traditionally a matter of state concern." Rypma and later Miller, Fielding, and Pitts (1992) called for the creation of a model state law to regulate sport agents. Rympa's (1990) proposed model state law, "The Sports Agency Act," largely resembles the UAAA, in that it called for the

\footnotetext{
$\overline{42}$ Id. at Bylaw 12.1.2 (a) - (b).

${ }^{43}$ Id. at Bylaw 12.3.1.3.

${ }^{44}$ Id. at Bylaw 12.1.2 (d).

${ }^{45}$ Id. at Bylaw 12.3.4 - 12.3.4.2.

${ }^{46}$ David Lawrence Dunn, Regulation of Sports Agents: Since at First It Hasn't Succeeded, Try Federal Legislation, 39 Hastings L.J. 1031, 336-37 (1988) (discussing a model federal regulatory framework governing sport agents).
} 
state licensure of sport agents and, “... restrictions on sports agents' activities in intercollegiate athletics" to protect the eligibility interests of NCAA student-athletes. ${ }^{47}$ Similarly, Miller, Fielding, and Pitts (1992) called for provisions that would later be adopted into the UAAA, namely, criminal penalties and specified prohibitions for sport agents. ${ }^{48}$

In the early 2000s, following the enactment of SPARTA and the UAAA, literature surrounding sport agents and NCAA student-athletes shifted to analyzing the effectiveness of the UAAA and SPARTA in governing the relationship between sport agents and NCAA student-athletes. Sudia and Remis (2001) provided a history of the UAAA to assert that it was "... one of the best athlete agent statutes in existence," but posited that the law presented several loopholes, which despite its existence, would allow sport agents to engage in unethical conduct causing NCAA student-athletes to become ineligible. ${ }^{49}$ Willenbacher (2004) theorized that neither SPARTA nor the UAAA were enough to eradicate agents' unethical behavior, as the criminal and civil penalties provided for under each were not significant enough to deter agents from partaking in unethical conduct that could harm NCAA student-athletes. Willenbacher called for the creation of a national sport agent registry by Congress as a method to curb agents' unethical practices. ${ }^{50}$

In the 2010s, research related to the relationship between sport agents and NCAA student-athletes shifted to scholars highlighting the inadequacies of the UAAA and SPARTA to govern the relationship and proposing new regulatory models. Nelson (2012) wrote,

Despite the multiple means by which agents are regulated, the current regulatory scheme is generally ineffective at preventing and deterring athlete agents from engaging in improper behavior. The laws are rarely enforced, and when they are, punishments fail to adequately penalize violators enough to deter others from committing future violations. ${ }^{51}$

\footnotetext{
${ }^{47}$ Curtis D. Rypma, Sports Agents Representing Athletes: The Need for Comprehensive State Legislation, 24 VAL. U. L. REv. 481, 514-19 (1990) (presenting a model state regulatory framework governing sport agents).

${ }^{48}$ Lori K. Miller, Lawrence W. Fielding and Brenda G. Pitts, A Uniform Code to Regulate Athlete Agents, Journal of Sport \& Social Issues, Vol. 16, Issue 2, 98-100 (1992) (presenting suggestions for how to develop a model regulatory code for the state regulation of sport agents).

49 Diane Sudia and Rob Remis, The History Behind Athlete Agent Regulation And The "Slam Dunking Of Statutory Hurdles,” 8 Vill. Sports \& EnT. L.J. 67, 69; 84-91 (2001) (identifying Constitutional vagueness, jurisdictional defects and state regulatory exemptions as potential defenses for sport agents mitigating the effectiveness of the UAAA).

${ }^{50}$ Eric Willenbacher, Regulating Sports Agents: Why Current Federal And State Efforts Do Not Deter The Unscrupulous Athlete-Agent And How A National Licensing System May Cure The Problem, 78 St. John's L. Rev. 1225, 1233-53 (2004) (asserting creation of a federal registry requiring any sport agent representing clients to be licensed and revoking licenses or representation opportunities from unlicensed sport agents representing clients would solve the problem of unscrupulous agents representing athlete clients).

${ }_{51}$ Timothy G. Nelson, Flag on the Play: The Ineffectiveness of Athlete-Agent Laws and Regulations - and How North Carolina Can Take Advantage of a Scandal to Be a Model for Reform, 90 N.C.L. REv. 800, 820-21 (2012).
} 
In asserting this, Nelson argued SPARTA, which is enforced by the Federal Trade Commission ("FTC"), is limitedly effective due to the minor nature of the penalties allowed for under the law. These penalties include the issuance of a cease and desist letter for the first violation and fines of up to $\$ 16,000$ for subsequent violations. SPARTA is also used in conjunction with the UAAA in states that have adopted the UAAA, as SPARTA provides states' attorney general authority to sue under SPARTA. While monetary damages available under individual states' iterations of the UAAA tend to be greater than those under SPARTA, Nelson asserts that they are still ".... too low to serve as effective deterrents .... 52 The minimal monetary damages that can be sought under the UAAA and SPARTA may preclude states' attorney general from enforcing the laws, as Nelson found in 2012 that "[O]nly two ... states, Alabama and Texas, reported taking disciplinary action against agents in recent years." ${ }^{53}$ To address the perceived ineffectiveness of SPARTA and the UAAA, Nelson proposed states increase the monetary damages allowed for under the laws and enhance enforcement of the laws by hiring full-time state members. ${ }^{54}$

Others question the efficacy of SPARTA and the UAAA by asserting the laws "... subordinate the interests of both athletes and their agents to ... the NCAA." ${ }^{55}$ Edelman (2013) asserted the UAAA subordinates the interest of athletes to the NCAA by writing the NCAA's amateurism standard into law by “... fix[ing] student-athletes' wages at zero ..." ${ }^{156}$ Edelman also questioned the effectiveness of SPARTA in protecting NCAA student-athletes' rights in that the law does not create a cause of action for NCAA student-athletes "... harmed by their agents." ${ }^{157}$ To address these perceived issues, Edelman suggested a new sport agent law should be enacted focusing on three core themes: “... principal protection, universality, and minimizing conflicts of interest." 58

Finding SPARTA ineffective due to the irregularity of its enforcement, Masteralexis, Masteralexis, and Snyder (2013) called for the creation by Congress of the Sport Agent Accountability Board ("SPAAB"), “... an independent nonprofit corporation ..." existing to:

... promulgate rules, regulations and a code of conduct for the certification and discipline of all agents who represent professional athletes in the United States. The chief duties of the SPAAB will be to certify sports agents who intend to conduct business in the U.S., establish quality control and ethical standards for those agents, conduct inspections of

\footnotetext{
${ }^{52} \mathrm{Id}$. at 822 .

${ }^{53}$ Id. at $821-23$.

${ }^{54}$ Id. at 831-33 (referencing Arkansas and Oklahoma's adoption of higher monetary damages amounts and identifying different roles an enforcement staff member could serve).

${ }_{55}$ Marc Edelman, Disarming the Trojan Horse of the UAAA and SPARTA: How America Should Reform its Sports Agent Laws to Conform with True Agency Principles, 4 Harv. J. SPORTS \& ENT. L. 145,147 (2013).

${ }^{56} \mathrm{Id}$. at 172.

${ }^{57} \mathrm{Id}$. at 179.

${ }^{58}$ Id. at $184-85$.
} 
sports agent firms, conduct investigations and disciplinary proceedings and impose appropriate sanctions and enforce compliance with agent laws and regulations. ${ }^{59}$

Masteralexis et al. asserted that the self-regulation model of the SPAAB would standardize the rules agents must adhere to nationally and create greater transparency of the sport agent industry for athletes, resulting in less exploitation and more competent representation. ${ }^{60}$

While many scholars have argued for the need of enhanced regulatory mechanisms to govern the relationship between sport agents and NCAA student-athletes, others have proposed policies to safeguard the interests of NCAA student-athletes. Wilde (1992) asserted that career counseling panels composed of faculty members at NCAA member institutions could be utilized to "... advise student-athletes about future professional careers, review proposed professional sports contracts, and meet with the student-athletes and representatives of professional teams." ${ }^{\circ 1}$ Analyzing and discussing the process whereby NCAA student-athletes pursue careers as professional athletes, Wong, Zola, and Deubert (2011) found,

... there is a clear need for more education and knowledge for ... student-athletes ... Better educated student-athletes are more likely (although not always) to make better decisions on when to go pro, how to make legal and business decisions, and how to avoid breaking rules (NCAA and state agent legislation). ${ }^{62}$

In this regard, Wong et al. advocated for NCAA institutions to adopt PSCPs, allowed under the NCAA bylaws. The authors asserted that appropriately funding and utilizing PSCPs allows member institutions to ensure NCAA student-athletes receive unbiased advice on their decision to turn professional, which should "... increase a student-athlete's chances at having a successful professional career." ${ }^{\circ 3}$

Building upon the identified need in the literature for more educational programming and resources for NCAA student-athletes on sport agents, Vlitz, Seifried, and Foreman (2014) conducted a survey on NCAA Division I FBS member institutions' Agent Days and literature provided to NCAA student-athletes on agents. The scholars sought information on whether,

\footnotetext{
59 James Masteralexis, Lisa Masteralexis, and Kevin Snyder, Enough Is Enough: The Case For Federal Regulation Of Sport Agents, 20 Vill. Sports \& ENT. L.J. 69, 97-99 (2013).

${ }^{60}$ Id. at 103-04.

${ }^{61}$ T. Jesse Wilde, The Regulation of Athlete-Agents, 2 J. Legal Aspects Sport 18, $26-27$ (1992) (asserting that a provision in the NCAA bylaws allowing for the adoption by member institutions of career counseling panels could be more effective if member institutions were allowed to solicit qualified, non-faculty members to serve on said panels).

${ }^{62} \mathrm{Id}$. at 595

${ }^{63}$ Glenn M. Wong, Warren Zola, Chris Deubert, Going Pro In Sports: Providing Guidance To Student-Athletes In A Complicated Legal \& Regulatory Environment, 28 CARdozo ArTs \& EnT. L.J. 601 (2011) (highlighting the benefits of PSCPs and arguing for the widespread adoption and funding of PSCPs to assist NCAA student-athletes in their decision to turn professional).
} 
a) The universities supplied student-athletes with documents or presentations regarding sports agents; b) the documents/presentations which are supplied to the student-athletes could be sent to [them]; c) the universities support an agent day for their student-athletes; and d) any sports other than football receive documents/presentations regarding agents. ${ }^{64}$

Receiving responses from 29 NCAA Division I FBS member institutions, the results showed $60 \%$ of the schools provided documentation to NCAA student-athletes on sport agents. Five of the 12 schools providing information to NCAA student-athletes on sport agents appeared to only provide the information to NCAA football players. Only $15 \%$ of responding member institutions indicated they host an Agent Day. ${ }^{65}$ Vlitz et al.'s (2014) research did not analyze materials provided by member institutions to NCAA student-athletes on sport agents to identify emerging themes. Rather, the scholars' research merely sought to determine if information on sport agents was shared with NCAA student-athletes and if Agent Days were held at the NCAA Division I FBS level.

A preceding call for the need to share more information on sport agents with NCAA student-athletes was made by Arkell (1997). Arkell argued member institutions should provide NCAA student-athletes information on sport agents upon signing the National Letter of Intent. Arkell also proposed that every member institution host annual meetings for all NCAA student-athletes to educate them on potential improper dealings with sport agents. ${ }^{66}$ Alternatively, others asserted that regulations like the UAAA and the NCAA Division I Manual's bylaws on amateurism and agents could harm NCAA student-athletes in their decision to turn professional, as NCAA student-athletes would not be able to seek professional advice on their careers as professional athletes. ${ }^{67}$

Researchers agree inadequacy exists in the current legal and governance mechanisms regulating the relationship between sport agents and NCAA student-athletes, as NCAA student-athletes are not fully protected from unethical and corrupt sport agents and risk jeopardizing their NCAA eligibility.

While many scholars posit this inadequacy can be erased through amending current laws regulating sport agents or enacting additional laws, one must question, given the current and extensive regulatory structure, whether such measures would fully address the issue. Arguably, these concerns would still persist given the reluctance by states and the federal government to enforce laws currently on the books related to sport agents. Given this, to best protect NCAA student-athletes as it relates to their relationship with sport agents, future

\footnotetext{
${ }^{64}$ Ross Vlitz, Chad Seifried, and Jeremy Foreman, An Analysis of Sports Agent Regulation in Intercollegiate Athletics: A Call for Cooperation, 24 J. Legal Aspects of Sport 62, 70 (2014). Do And What Institutions Should Do In Response, 4 Sports LAW. J. 147, 165 (1997) (presenting proposed policies to safeguard NCAA student-athletes from unscrupulous sport agents).

${ }^{67}$ Jan Stiglitz, NCAA-Based Agent Regulation: Who Are We Protecting?, 67 N.D. L. Rev., 215, 225-226 (1991) (questioning the effectiveness of state regulations of sport agents and the NCAA's Bylaws on amateurism and agents related to preparing NCAA student-athletes to make athletic-based career decisions).
} 
efforts should focus more heavily on providing thorough and relevant education to NCAA student-athletes related to sport agents and regulating the relationship between sport agents and NCAA student-athletes at the member institution level.

\section{The FBI's Investigation into Division I Men's Basketball Demonstrates The Need for Stronger Policies on Sport Agents by NCAA Division I FBS Member Institutions}

On September 26, 2017, the Department of Justice announced the arrest of 10 people for their alleged involvement in corruption schemes related to Division I NCAA basketball. The arrests came after a multi-year investigation by the FBI and United States Attorney's Office into “... the criminal influence of money on coaches and student-athletes who participate in intercollegiate basketball governed by the NCAA." The investigation revealed,

... athlete advisors-including financial advisors and business managers, among others - allegedly paid bribes to assistant and associate head basketball coaches at NCAA Division I universities and sometimes directly to student-athletes at those universities, facilitated by the coaches. In exchange for the bribes, the coaches agreed to pressure or exert influence over student-athletes under their control to retain the services of the bribe-payors once the athletes entered the National Basketball Association ("NBA"). ${ }^{68}$

The aforementioned scheme involved four NCAA Division I FBS men's basketball coaches, two shoe company executives, a financial advisor, a clothier, and a professional athlete business manager/runner. Charges for the defendants included: conspiracy to commit bribery, payments of bribes, honest services fraud conspiracy, honest services fraud, wire fraud conspiracy, wire fraud, Travel Act conspiracy, and money laundering conspiracy. Notably, none of the individuals charged under the investigation were charged with violations of the UAAA or SPARTA, further calling into question the laws' abilities to successfully safeguard the rights and interests of NCAA student-athletes related to sport agents. ${ }^{69}$

The conclusion of trials in the cases in 2019 left questions over whether the multi-year FBI and Department of Justice investigation changed the landscape of college basketball and ensured greater protections for NCAA athletes. ${ }^{70}$ Notably,

\footnotetext{
${ }^{68}$ U.S. Attorney Announces The Arrest Of 10 Individuals, Including Four Division I Coaches, For College Basketball Fraud And Corruption Schemes, supra note 1 (detailing an alleged corruption scheme uncovered by the FBI and United States Attorney's Office related to sport agents and NCAA Division I men's basketball coaches and athletes).

${ }^{69}$ Id. (listing charges against defendants in the FBI and United States Attorney's Office's investigation into alleged corruption in NCAA Division I men's basketball).

70 Andy Staples, What Has the NCAA-or Anyone-Learned From the College Basketball Black Market's Time on Trial?, SPORTs Illustrated (May 9, 2019), https://www.si.com/college-basket$\underline{\text { ball/2019/05/09/ncaa-trial-fbi-bribery-corruption-mark-emmert }}$
} 
every NCAA basketball coach charged under the alleged scheme accepted a plea deal and largely avoided prison. Lamont Evans, a former University of South Carolina and Oklahoma State University assistant men's basketball coach, and Book Richardson, a former University of Arizona assistant men's basketball coach, both received three-month prison sentences after pleading guilty to conspiracy to commit bribery. ${ }^{71}$ Former University of Southern California assistant men's basketball coach Tony Bland also pled guilty to conspiracy to commit bribery, but was only sentenced to two years of probation and 100 hours of community service after a judge found he overcame a difficult childhood and was recognized by peers for strong character. ${ }^{72}$ Former NBA player and Auburn University assistant men's basketball coach Chuck Person pled guilty to conspiracy to commit bribery but also avoided jail time by being sentenced to two years of probation and 200 hours of community service. ${ }^{73}$ The top adidas executive in the investigation, Jim Gatto, received a nine-month prison sentence, while adidas consultant Merl Code and runner Christian Dawkins each received six-month prison sentences after the three were convicted at trial on charges of wire fraud and conspiracy ${ }^{74}$ Clothier Rashan Michel, also a former NBA referee, pled guilty to conspiracy to commit bribery and is scheduled to be sentenced in September $2019 .{ }^{75}$ Financial advisor Munish Sood, the first to accept a plea deal in the case, testified for the prosecution. ${ }^{76}$

While questions remain over the effects of the investigation on college basketball recruiting and protecting NCAA athletes' rights, an NCAA commissioned report written under the leadership of former Secretary of State Condoleezza Rice recommended changes the NCAA should adopt to ensure the integrity of NCAA Division I men's basketball. ${ }^{77}$ In a 53-page report, the Commission on College Basketball made numerous recommendations to the NCAA, including calling on the NBA and the National Basketball Players Association ("NBPA")

\footnotetext{
${ }^{71}$ Matt Norlander, College basketball bribery trial: As another coach is sentenced to prison, it's time for the NCAA to act, CBS SPORTS (June 7, 2019), https://www.cbssports.com/college-basketball/news/college-basketball-bribery-trial-as-another-coach-is-sentenced-to-prison-its-time-forthe-ncaa-to-act/

${ }^{72}$ Matt Norlander, College basketball corruption trial: Ex-USC assistant coach Tony Bland avoids prison, gets two years probation, CBS SPORTS (June 5, 2019), https://www.cbssports.com/ college-basketball/news/college-basketball-corruption-trial-ex-usc-assistant-coach-tony-blandavoids-prison-gets-two-years-probation/

${ }^{73}$ Larry Neumeister, Former Auburn assistant basketball coach avoids prison, Associated Press (July 17, 2019), https://apnews.com/42c9f7eb4cc54facac46038e558582d8

${ }^{74}$ Michael McCann, Lenient Sentencing in College Hoops Fraud Convictions Sends a Message, Even Before Appeals, Sports Illustrated (March 5, 2019), https://www.si.com/college-basketball/2019/03/05/ncaa-fbi-investigation-corruption-fraud-lenient-sentencing

${ }^{75}$ Mark Schlabach and Paula Lavine, NCAA scandal defendant Michel accepts plea deal, ESPN. COM (May 7, 2019), https://www.espn.com/mens-college-basketball/story//id/26694244/ncaascandal-defendant-michel-accepts-plea-deal

${ }^{76} I d$. at 69.

${ }^{77}$ Nat'l Collegiate Athletic Ass'n, Commission on College Basketball Charter, NCAA.org, http:// www.ncaa.org/governance/commission-college-basketball-charter
} 
to end the "one-and-done" model of NBA eligibility; allowing athletes to retain their eligibility if they aren't drafted professionally; and promoting increased transparency in NCAA men's basketball. Related to agents, the commission recommended that the NCAA begin certifying agents (similar to the process followed by professional leagues' players associations) and allow NCAA certified agents to provide elite-level athletes advice as early as their high school careers. The commission also recommended that the NCAA investigate how to incentivize good agent behavior, with the certification process serving as a conduit for said behavior. ${ }^{78}$

In response to the recommendations from the Commission on College Basketball's report, in August 2019 the NCAA created a set of certification requirements for agents seeking to represent underclassmen exploring their NBA Draft options. The criteria requires agents to hold a bachelor's degree, be certified by the NBPA for three consecutive years, hold professional liability insurance, and pass an in-person examination administered by the NCAA. ${ }^{79}$ Since 2012 , the NCAA's definition of "agent" has included certified contract advisors, financial advisors, marketing representatives, brand managers, and their employees. ${ }^{80}$ Thus, any payment by a financial advisor or business manager to an NCAA student-athlete or associate-like that allegedly involved in the FBI and United States Attorney's Office's investigation into NCAA Division I men's basketball—would violate bylaws in the NCAA Division I Manual related to sport agents. As of the date of publication, the NCAA has not announced the imposition of infractions against any of the criminally charged coaches' related member institutions.

Furthermore, while the bylaws in the NCAA Division I Manual related to sport agents do not directly specify or limit any behaviors by NCAA coaches, NCAA coaches are required to “... act with honesty and sportsmanship at all times" and uphold a standard of ethical conduct. ${ }^{81}$ This standard of ethical conduct deems it unethical for a coach to receive "... benefits ... for facilitating or arranging a meeting between a student-athlete and an agent, financial advisor or a representative of an agent or advisor (e.g., "runner')." ${ }^{\prime 2}$ As of the date of publication, the NCAA has not announced infractions against any of the charged coaches' related member institutions under Bylaw 10.01.1.

These allegations spanning multiple years and various NCAA member institutions related to an alleged scheme between sport agents and individuals whom many NCAA student-athletes trust the most-coaches-highlight the need for adoption and enforcement of more widely accepted policies related to sport agents at the NCAA Division I FBS member institution level.

\footnotetext{
${ }^{78}$ Commission on College Basketball, Commission on College Basketball: Report And Recommendations To Address the Issues Facing Collegiate Basketball (April 2018), NCAA.org, http:// www.ncaa.org/sites/default/files/2018CCBReportFinal_web_20180501.pdf

79 See Michael McCann, How Rich Paul Could Build a Case Against the NCAA Over Its New Criteria for Agents, Sports Illustrated (Aug. 6, 2019), https://www.si.com/college-basketball/2019/08/06/ncaa-criteria-exclude-rich-paul-others-certified-nbpa

${ }^{80}$ Nat'l Collegiate Athletic Ass'n, supra note 4 at Bylaw 12.02.1.1.

${ }^{81}$ Id. at Bylaw 10.01.1.

${ }^{82}$ Id. at Bylaw 10.1 (d).
} 


\section{Method}

This inquiry researched NCAA Division I FBS member institutions' sport agent policies to conduct textual analyses to identify emerging themes. The purpose of this research was to present findings on member institutions' sport agent policies to better understand how individual athletic departments use the autonomy granted under the NCAA Division I Manual to regulate sport agents and educate NCAA student-athletes on sport agents. ${ }^{83}$ As researchers have identified ineffectiveness in the UAAA, SPARTA, and the NCAA Division I Manual in regulating the relationship between sport agents and NCAA student-athletes, this research sought to identify whether NCAA member institutions' sport agent policies included additional safeguards to govern the relationship.

As of the date of the study, thematic analysis of NCAA Division I FBS member institutions' sport agent policies had not been conducted. Thus, a method adopted by Sanderson (2011) to analyze NCAA Division I member institutions' social media policies was utilized and modified for this study. ${ }^{84}$

First, NCAA Division I FBS member institutions $(N=128)$ were identified by accessing the NCAA website and using an available directory to search first for Division I member institutions and then sort by Division I member institutions that are also members of the FBS. ${ }^{85}$ Sanderson (2011) evaluated the social media policies of every NCAA Division I institution across the FBS and Football Championship Subdivision ("FCS"). The present study only analyzed the sport agent policies of NCAA Division I FBS institutions, as Vlitz et al.'s (2014) study focused only on agent materials provided to student-athletes and Agent Days hosted at NCAA Division I FBS member institutions. ${ }^{86}$

Next, athletic department websites for NCAA Division I FBS member institutions were accessed. Each athletic department's website was evaluated to locate the presence of a sport agent policy. More than 70\% (70.3) of NCAA Division I FBS member institutions' athletic department websites $(N=90)$ contained a sport agent policy. Sport agent policies could not be located on 38 NCAA Division I FBS member institutions' athletic department websites.

After collecting every publicly available NCAA Division I FBS member institution sport agent policy, a data analysis modeled after Sanderson's (2014) social media policy analysis was conducted. First, "[t]he policies were initially read to get a general sense of the messages contained in them" and to identify terms and provisions within the policies exceeding the scope of the UAAA, SPARTA, and NCAA Division I Manual's bylaws on sport agents. ${ }^{87}$ After an initial reading, a

\footnotetext{
${ }^{83}$ See, Richard T. Cober, Douglas J. Brown, and Paul E. Levy, Form, Content, And FunCtion: An EValuative Methodology For Corporate Employment Websites, 43 Human Resource Mgmt 201 (2004) (utilizing textual content qualitative analysis to evaluate corporate organizations' websites to identify how they use websites to advertise employment opportunities).

${ }^{84}$ Jimmy Sanderson, To Tweet or Not to Tweet: Exploring Division I Athletic Departments' Social-Media Policies, 4 InT'L J. Sport Comm., 492, 498-00 (2011).

${ }^{85}$ NCAA, Directory, https://web3.ncaa.org/directory/memberList?type=12\&division=I (last visited May 3, 2018).

86 Vlitz, supra note 61 at 70.

${ }^{87}$ Sanderson, supra note 66 at 499.
} 
thematic analysis was conducted on each member institution's sport agent policy using constant comparative methodology. ${ }^{88}$ Policies were individually counted as separate units of analysis. The initial thematic analysis revealed the presence of language related to specific requirements sport agents must adhere to in order to comply with individual member institutions' sport agent policies. The initial thematic analysis also revealed the presence of language related to education provided by member institutions on sport agents per their policies. The policies were read again and statements about sport agent representation requirements and education on sport agents were extrapolated and classified into emergent categories based on how each theme was being presented. ${ }^{89}$ These categories were placed into a coding scheme to assess the form of the policies, which can be found in Appendix A..$^{90}$

After the initial creation of the coding scheme, each policy was re-read and compared to the coding scheme to determine the usefulness of the thematic categories identified and placed in the coding scheme. At this stage, an additional theme of incentives to sport agents for upholding sport agent policies was identified as emerging. The policies were then re-read again to extrapolate statements related to sport agent incentives, which were classified into emergent categories based on the incentive provided. The identified emergent categories were included in the coding scheme (see Appendix A). ${ }^{91}$

The policies were re-read again and compared to the coding scheme to ensure that themes were "... reduced ... as much as possible while still preserving meaning." Themes were re-read and categories were reduced on the coding scheme until "... new observations failed to add significantly to existing categories." This process continued "... until new observations failed to add significantly to existing categories." The coding scheme was created in a manner demonstrating the possibility of multiple themes existing in individual sport agent policies. ${ }^{92}$

\section{Results}

Thematic analysis of NCAA Division I FBS member institutions' sport agent policies revealed the presence of three content themes existing beyond language related to the UAAA, SPARTA, and NCAA bylaws on sport agents: sport agent requirements for compliance with member institutions' sport agent policies; education on sport agents; and incentives to sport agents for upholding member institutions' sport agent policies. Each content theme contained sub-themes. Further discussion of each theme and its respective sub-themes is included in the following sections.

\footnotetext{
${ }^{88}$ Id.; Barney G. Glaser, Anselm L. Strauss, The Discovery of Grounded Theory Strategies for Qualitative Research (1967) (developing the constant comparative method of qualitative analysis).

89 Sanderson, supra note 66 at 499.

${ }^{90}$ Cober, supra note 65 at 204 (discussing the creation of a coding form to collect data in a thematic analysis using the constant comparative method).

91 Sanderson, supra note 66 at 499.

${ }_{92} I d$.
} 


\section{A. Sport Agent Requirements for Compliance with Member Institutions' Sport Agent Policies}

The most prevalent theme in NCAA Division I FBS member institutions' sport agent policies was that of sport agent requirements for compliance with member institutions' policies. More than 90\% (92) of policies contained requirements for sport agents to adhere to beyond those in the UAAA, SPARTA, or the NCAA Division I Manual's bylaws. Policies including this theme contained language specifying behaviors sport agents were required to engage in or refrain from engaging in to comply with the member institution's sport agent policy. These behaviors included the following sub-themes: a registration requirement; communication requirements; and representation requirements for sport agents signing NCAA student-athletes from said member institutions.

More than $70 \%$ of policies required sport agents to register with the respective member institution's athletics department before engaging in communication with and/or representing NCAA student-athletes from said member institution. Nearly one quarter $(24.4 \%)$ of policies required agents to uphold various communication standards when communicating with NCAA student-athletes from the member institution. Only $4.4 \%$ of policies contained representation requirements specifying particular skills and/or behaviors an agent signing an NCAA student-athlete from the member institution as a client must possess or uphold.

Table 1 provides examples of the types of sport agent restrictions present in NCAA Division I FBS member institutions' sport agent policies. 
Table 1. Restrictions on Sport Agents Found in Member Institutions' Sport Agent Policies

\begin{tabular}{|c|c|}
\hline Sub-Theme & Examples \\
\hline Registration requirement & $\begin{array}{l}\text { "In order to protect Razorback student-athletes and the University from } \\
\text { potential NCAA violations, the athletics department policy requires all agents } \\
\text { and advisors to register with the Razorback Athletics Compliance Office. In } \\
\text { addition, Arkansas State law requires agents to register with the Arkansas } \\
\text { Secretary of State." }\end{array}$ \\
\hline Communication requirement & $\begin{array}{l}\text { "Student-athletes must notify the Office of NCAA Compliance any time they } \\
\text { have contact with an agent."' } \\
\text { "Sports agents, financial advisors, and anyone else recruiting San Jose } \\
\text { State University (SJSU) student-athletes for any reason, are prohibited from } \\
\text { having any verbal or in-person contact with SJSU freshman or sophomore } \\
\text { student-athletes, their families or friends. Contact with SJSU junior or senior } \\
\text { student-athletes is subject to the Agent Calendar below."c } \\
\text { "It is permissible for agents to send written materials to student-athletes, } \\
\text { but the University of Colorado requests that agents send an identical copy of } \\
\text { the written materials to the Office of Compliance Services at the University } \\
\text { of Colorado. The University of Colorado discourages its student-athletes from } \\
\text { contacting agents until their eligibility has expired. Similarly the University } \\
\text { encourages parents of student-athletes to refrain from having telephone } \\
\text { contact or in-person contact with an agent until the student-athlete's eligibility } \\
\text { has expired. The University recommends that all agents only provide written } \\
\text { materials to student-athletes and their parents, and only have contact with } \\
\text { student-athletes if the contact is initiated by the student-athlete. This contact } \\
\text { includes telephone and in-person contact. Also, you, your employees, or } \\
\text { runners may not position yourselves after athletic contests to 'bump' into or } \\
\text { have contact with a student-athlete or his/her family. The rules governing } \\
\text { contact are still in affect at athletic contests or events that take place at sites } \\
\text { other than the University of Colorado campus."d }\end{array}$ \\
\hline Representation requirement & $\begin{array}{l}\text { "The agent further agrees to: i. Provide permissible, honest, lawful, and } \\
\text { ethical services to the student-athlete; ii. Avoid conflicts of interest which may } \\
\text { compromise the interests of student-athletes ..." }\end{array}$ \\
\hline
\end{tabular}

\footnotetext{
${ }^{a}$ University of Arkansas, Agents \& Advisors, (2018), http://www.arkansasrazorbacks.com/compliance/agents/ (last visited May 5, 2018).

${ }^{\mathrm{b}}$ UNLV Compliance, Agents and Financial Planners, http://www.unlvrebels.com/compliance/ agents.html (last visited May 4, 2018).

c San Jose State University Athletics, Compliance Office Player-Agent Policy, (April 2,

2013), http://grfx.cstv.com/photos/schools/sjsu/genrel/auto_pdf/2013-14/misc non_event/player-agent-policy.pdf (last visited May 5, 2018).

${ }^{d}$ University of Colorado Office of Compliance Services, Agent Policy, (2016), http://cubuffs.com/ documents/2017/3/24//2016 17 CU_Agent_Policy.pdf?id=6777 (last visited May 4, 2018).
}

e Arizona State University, Athlete Agent Policy and Process, https://sundevilcompliance.asu.edu/

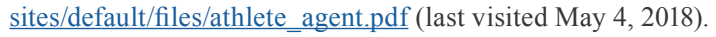




\section{B. Education on Sport Agents}

A second emerging theme present in NCAA Division I FBS member institutions' sport agent policies was a requirement to provide NCAA student-athletes or coaches and athletics department staff members education on sport agents. Two sub-themes were identified under this theme: education on sport agents for NCAA student-athletes and education on sport agents for coaches and athletics department staff members.

Only $4.4 \%$ of policies contained requirements for respective NCAA member institutions to provide NCAA student-athletes education on sport agents, while just $1.1 \%$ of policies contained requirements for respective NCAA member institutions to provide coaches and athletics department staff members education on sport agents. It is worth noting that as per Vlitz et al. (2014), member institutions may nonetheless provide NCAA student-athletes with education on sport agents through respective Agent Days, despite not specifically calling out the requirement for such an event in their publicly available sport agent policy.

Table 2 provides examples of education-related themes found in NCAA member institutions' sport agent policies.

Table 2. Education Requirements Found in Member Institutions' Sport Agent Policies

\begin{tabular}{|l|l|}
\hline Sub-Theme & Examples \\
\hline $\begin{array}{l}\text { Education of NCAA } \\
\text { student-athletes on sport } \\
\text { agents }\end{array}$ & $\begin{array}{l}\text { "GT student-athletes will be educated about Athlete Agent issues at least } \\
\text { once per year. This education will take place in conjunction with beginning of } \\
\text { the year squad meetings. Additionally, Athlete Agent issues will be covered } \\
\text { any time the compliance office deems necessary and also when any GT team } \\
\text { qualifies for post-season play and must complete a required NCAA affidavit. } \\
\text { Former student-athletes that return to GT to use GTAA facilities will be educated } \\
\text { on the prohibition on solicitation of current student-athletes when they sign } \\
\text { the required institutional liability waiver." }\end{array}$ \\
\hline $\begin{array}{l}\text { Education of coaches and } \\
\text { athletics department staff } \\
\text { members on sport agents }\end{array}$ & $\begin{array}{l}\text { "Coaches and ICA staff members (especially trainers, managers, and academic } \\
\text { advisors; those dealing closely with student-athletes on a daily basis) will } \\
\text { be educated as to what they should be alert for as indicators of changes in } \\
\text { lifestyles of student-athletes that may be a result of improper inducements } \\
\text { from 'Agents'/intermediaries. They will be instructed in the procedures to } \\
\text { report such changes to the appropriate director of athletics for follow-up." }\end{array}$ \\
\hline
\end{tabular}

${ }^{a}$ Georgia Tech Compliance Office, Athlete Agent Policy, (March, 2014), http://grfx.cstv.com/ photos/schools/geot/genrel/auto_pdf/2016-17/misc_non_event/agent-policy.pdf (last visited May 4, 2018).

b Arizona Compliance, Agents, http://arizonawildcats.com/sports/2014/6/12/209521182.aspx (last visited May 4, 2018).

\section{Incentives to Sport Agents for Upholding Sport Agent Policies}

The third theme present in NCAA Division I FBS member institutions' sport agent policies was that of incentives to sport agents for upholding NCAA member institutions' sport agent policies. More than 15\% (15.6) of policies 
presented incentives for sport agents who adhere to member institutions' sport agent policies.

The identified incentives emerging from sport agent policies included the following sub-themes: athletics department-sponsored publicity of the sport agent ( $8.9 \%$ of policies); ability to participate in athletics department-hosted interviews with NCAA student-athletes ( $7.8 \%$ of policies); ability to participate in non-Agent Day workshops (1.1\% of policies); and ability to participate in Agent Day (3.3\% of policies). Table 3 provides examples on the types of incentives member institutions provide sport agents who adhere to their respective sport agent policies.

\section{Table 3. Sport Agent Incentives}

\begin{tabular}{|l|l|}
\hline Theme & Examples \\
\hline $\begin{array}{l}\text { Athletics } \\
\text { department-sponsored } \\
\text { publicity of sport agent }\end{array}$ & $\begin{array}{l}\text { "Registered agents are invited to submit promotional materials to the UCLA } \\
\text { Compliance Department. Information provided in the registration form and } \\
\text { promotional materials will be included in the agent database and library for } \\
\text { student-athletes to review when they seek information about agents."a }\end{array}$ \\
\hline $\begin{array}{l}\text { Ability to participate in } \\
\text { athletics department-hosted } \\
\text { interviews with NCAA } \\
\text { student-athletes }\end{array}$ & $\begin{array}{l}\text { "Baylor will host and schedule student-athlete interviews of athlete-agents ... } \\
\text { All athlete-agents registered with the State of Texas will be notified in writing } \\
\text { of the scheduled interview period at least 30 days in advance. Only those } \\
\text { athlete-agents registered with Baylor and the State of Texas will be permitted } \\
\text { to participate ..." }\end{array}$ \\
\hline $\begin{array}{l}\text { Ability to participate in } \\
\text { non-Agent Day workshops }\end{array}$ & $\begin{array}{l}\text { "Once you receive approval from the PSCP, you are eligible to attend } \\
\text { PSCP sponsored events ... Annually, the PSCP assists the organization and } \\
\text { administration of the following events. March- Football Pro Timing Day: Draft } \\
\text { eligible football student-athletes will participate in combine style events in } \\
\text { front of NFL scouts. Agents in attendance must be registered with the PSCP. } \\
\text { April- Football Parents Education: Before the spring football game, parents of } \\
\text { football student-athletes are invited to an educational session preparing their } \\
\text { son for playing at the next level ..." }\end{array}$ \\
\hline $\begin{array}{l}\text { Ability to participate in Agent } \\
\text { Day }\end{array}$ & $\begin{array}{l}\text { "Once registered with the state and the Compliance Office, an agent/advisor } \\
\text { will be: ... Eligible to speak with Marshall student-athletes and participate in } \\
\text { on-campus Agent Days."d }\end{array}$ \\
\hline
\end{tabular}

\footnotetext{
${ }^{a}$ UCLA, Agent \& Amateurism Program Policy, July 1, 2012, https://ucla ftp.sidearmsports.com/ pdf9/2415185.pdf (last visited May 4, 2018).

${ }^{\mathrm{b}}$ Baylor Compliance, Athlete-Agent And Advisor Program, http://www.baylorbears.com/compliance/bay-compliance-agents.html (last visited May 4, 2018).

c Mizzou Compliance, Agents, https://mutigers.com/sports/2017/10/18/agents.aspx?id=999 (last visited May 4, 2018).

d Marshall Compliance, Agents \& Advisors Institutional Regulations, http://grfx.cstv.com/photos/ schools/mars/genrel/auto_pdf/2015-16/misc_non_event/institutional-regulations.pdf (last visited May 4, 2018).
} 


\section{Discussion}

Scholars assert the UAAA, SPARTA, and NCAA Division I Manual are ineffective in dissuading sport agents from engaging in unethical and corrupt behavior related to engaging with NCAA student-athletes. The autonomy given by the NCAA to Division I FBS member institutions to regulate the relationship between sport agents and NCAA student-athletes beyond the purview of the NCAA Division I Manual presents an opportunity to better safeguard this relationship from corruption.

Division I FBS member institutions' sport agent policies should be modeled to not only safeguard the rights and interests of NCAA Division I student-athletes, but incentivize sport agents to follow the respective policies, along with the UAAA, SPARTA, and NCAA Division I Manual's bylaws. Currently, the possibility of facing criminal prosecution or jeopardizing an NCAA student-athlete's eligibility are the only mechanisms to dissuade a sport agent from providing an NCAA student-athlete monetary benefits in an attempt to sway the NCAA student-athlete to sign with the sport agent's company. As demonstrated by the Division I men's basketball investigation and other recent cases involving alleged payments by sport agents to NCAA student-athletes, along with the limited prosecution by states and the federal government of cases involving these allegations, the possibility of these penalties does not fully deter sport agents from engaging in this behavior. Thus, if the NCAA and its Division I FBS member institutions want to create a system deterring this type of behavior, they must offer appealing benefits to sport agents who operate according to the law. Individual NCAA Division I FBS member institutions' sport agent policies can serve as the mechanism through which to create these incentives.

\section{A. A Model Institutional Sport Agent Policy}

In enacting sport agent policies, NCAA Division I member institutions should seek to uphold three goals: 1 . protect the rights and interests of NCAA Division I student-athletes; 2. educate NCAA Division I student-athletes on the role of and how to select sport agents; and 3. provide incentives for sport agents who uphold the respective policies, along with the UAAA, SPARTA, and NCAA Division I Manual.

As it relates to protecting the rights and interests of NCAA Division I student-athletes, individual member institutions' sport agent policies should be drafted to first mirror the UAAA and SPARTA. In this regard, the policies should require sport agents recruiting NCAA student-athletes to register with the NCAA student-athlete's respective member institution. The purpose of this registration would be to allow the member institution and its athletics compliance department to become aware of which sport agents are engaging with NCAA student-athletes enrolled at the member institution. Furthermore, the registration process would allow member institutions to collect meaningful data related to the sport agents' background and qualifications, which will be utilized to educate NCAA student-athletes, as discussed later.

Next, each member institution's policy should specify that sport agents are forbidden from providing NCAA student-athletes or anyone associated with 
them or the member institution anything of value to persuade the NCAA student-athlete to sign with the sport agent. Member institutions' policies should iterate that providing an NCAA student-athlete with anything of value beyond an NCAA athletics scholarship could jeopardize the NCAA student-athlete's eligibility and violates the UAAA and SPARTA. In this regard, member institutions' policies should specify that member institutions will seek the remedies available to them under the UAAA and SPARTA against sport agents found violating this provision. Private member institutions should also include a provision in their policies specifying that sport agents found to violate either the member institution's sport agent policy or the UAAA, SPARTA, or NCAA Division I Manual will be forbidden from entering campus and attending the member institution's NCAA sporting events. Specifying the remedies that will be sought against sport agents violating member institutions' policies and relevant laws regulating sport agents is necessary so that sport agents are educated on the ramifications they face for violating the respective provisions. However, educating sport agents on this matter is not enough. In order for this measure to serve to limit sport agents from violating the respective provisions, NCAA member institutions must specify that remedies will be actively pursued, and thereafter proactively engage appropriate litigation.

Similar to specifying that sport agents cannot provide anything of value to entice an NCAA student-athlete to sign with their respective agencies, member institutions' policies must also declare that sport agents cannot provide false or misleading information to NCAA student-athletes while recruiting them. This requirement not only complies with SPARTA, but creates an additional safeguard to protect the integrity of an NCAA student-athlete's decision to turn professional and future relationship with a sport agent. This additional safeguard will be cemented when member institutions utilize education on sport agents provided to NCAA student-athletes and incentives for sport agents, both discussed later, to ensure compliance with this provision.

The second element member institutions' policies on sport agents must contain is an education requirement. Education on sport agents must be provided to NCAA student-athletes upon the signing of the National Letter of Intent or statement of financial assistance. The reason for this is NCAA student-athletes in some sports, namely Division I men's basketball, often turn professional after their first year of competition. Thus, these individuals may be contacted by sport agents earlier than NCAA student-athlete peers in other sports. Thus, it is critical that education on sport agents begin as early as possible.

Thereafter, NCAA student-athletes must receive continuing education on sport agents on a quarterly basis, to keep topics and issues fresh in their mind and to present them with new findings on tactics utilized by unethical or unskilled sport agents to attract and sign clients. Furthermore, all members of the athletics department staff, along with the NCAA faculty athletics representative, should receive education quarterly on sport agents. It is necessary that these individuals be mandated to receive education on sport agents, as they are the university officials who most frequently come into contact with NCAA student-athletes. Thus, they have the greatest ability to engage with NCAA student-athletes on the issue of sport agents and may do this to either educate them on the proper selection 
of sport agents or could be used improperly by sport agents to sway NCAA student-athletes' decisions. Furthermore, athletics departments' policies should include a requirement of the athletics department to produce and supply educational literature on sport agents to NCAA student-athletes' families or guardians. By directly providing families or guardians with educational materials on sport agents and the laws governing them, member institutions can remove the risk of a family member or guardian unwittingly violating the NCAA Division I Manual's bylaws or being complicit in violating the UAAA or SPARTA.

Education on sport agents by member institutions must take a holistic approach and inform all constituents on the role of a sport agent, the legal duties of a sport agent, strategies to identify a qualified and ethical sport agent, and the laws governing sport agents. Education cannot serve to only inform NCAA student-athletes of the unethical and corrupt practices of some sport agents, but must also allow NCAA student-athletes to learn about the role an agent will play in their career and the positive impact a qualified and law-abiding agent can have on their career. In this regard, member institutions should share information supplied by sport agents on their registration form with NCAA student-athletes, their families, and members of the athletics department so they can assess the qualification and character of prospective sport agents. Education programs should serve to empower and enlighten NCAA student-athletes, their families and guardians, and athletics department staff members to direct and make a decision that has significant implications on an NCAA student-athlete's career trajectory and life in an unbiased and informed manner.

Finally, member institutions' sport agent policies must provide incentives for sport agents to adhere to said policies. One of the biggest criticisms of the UAAA and SPARTA is that the laws have done little to preclude sport agents from providing NCAA student-athletes items of value or false or misleading information. ${ }^{93}$ Thus, if member institutions want their sport agent policies to add value in protecting the rights and interests of NCAA student-athletes against unscrupulous sport agents, they must create incentives for sport agents to follow them.

Member institutions' sport agent policies must include incentives based on the recognition that the most difficult element of being a sport agent is recruiting clients to represent. ${ }^{94}$ Thus, one of the greatest incentives member institutions can provide sport agents in exchange for their compliance is access to potential clients. There are multiple ways member institutions can provide this access. First, member institutions can provide NCAA student-athletes with communication and informational materials from sport agents who register with the member institution. These communications can highlight the sport agent's background, qualifications, and history as a sport agent. Member institutions can also host on-campus informational sessions and interviews between registered sport agents and NCAA student-athletes. Furthermore, member institutions can allow

\footnotetext{
93 See Violation of sports agent laws tough to prosecute, supra note 15.

${ }^{4}$ See Justin Park, The Role of Athlete-Agents and the Law: A Conflict of Interest?, 29 BYU Prelaw Rev. 106, 108 (2015) (highlighting the extreme competition sport agents face in recruiting clients).
} 
registered agents to attend exclusive events, ranging from Agent Days, Football Pro Days, and other workshops. Requiring registration to access these incentives allows the member institution to verify the qualifications of sport agents, as member institutions should require sport agents to supply background and criminal records, and information on their qualifications and history as a sport agent. Providing these incentives serves the critical purpose of removing the need of a middleman from the recruitment of NCAA student-athletes by sport agents and allows the member institution to monitor the recruiting process.

\section{Conclusion}

The investigation by the FBI and U.S. Attorney's Office into improper dealings between coaches and sport agents in Division I men's basketball highlights the inadequacy of the UAAA, SPARTA, and NCAA Division I Manual to protect the rights and interests of NCAA student-athletes as it relates to sport agents. These rules and laws have existed for decades, yet violations of them persist with minimal prosecution of violators. Thus, the time has come to adopt new mechanisms to regulate the relationship between sport agents and NCAA studentathletes to best protect NCAA student-athletes. To do this, NCAA Division I FBS member institutions must each adopt and actively impose individual sport agent regulations. These sport agent regulations will be most effective if they address issues of sport agent regulation and requirements, educate NCAA student-athletes on the role and requirements of sport agents, and provide member institutionbased incentives to sport agents in exchange for complying with said policies.

\section{Appendix A}

Thematic Analysis of NCAA Division I FBS Member Institutions' Sport Agent Policies

Member Institution:

Member Institution Sport Agent Policy Web Address:

Sport Agent Requirements for Compliance with Member Institutions' Sport Agent Policies

1. Did the policy require this theme?. . . . . . Yes . . . . . No

2. Did the policy require the following sub-themes?

A. Registration with member institution's athletics department to communicate with and/or represent NCAA student-athletes from member institution

B. Uphold communication standards when communicating with NCAA student-athletes from the member institution

C. Possession of representation requirements related to skills and/or behaviors for signing an NCAA student-athlete from the member institution

\section{Education on Sport Agents}

1. Did the policy require this theme?. . . . . Yes . . . . . No 
2. Did the policy require the following sub-themes?

A. Education of NCAA student-athletes on sport agents

B. Education of coaches and athletics department staff members on sport agents

Incentives to Sport Agents for Upholding Sport Agent Policies

1. Did the policy include this theme? . . . . . . . Yes . . . . . . No

2. Did the policy include the following sub-themes?
A. Athletics department-sponsored publicity of sport agent
B. Ability to participate in athletics department-hosted interviews with NCAA student-athletes
C. Ability to participate in non-Agent Day workshops
D. Ability to participate in Agent Day 